\title{
EFFECT OF BIO-ENZYME STABILIZATION ON UNCONFINED COMPRESSIVE STRENGTH OF EXPANSIVE SOIL
}

\author{
Puneet Agarwal $^{1}$, Suneet Kaur ${ }^{2}$ \\ ${ }^{1}$ M.Tech. Scholar, Geotechnical Engineering, Maulana Azad national Institute of Technology, Bhopal, India \\ ${ }^{2}$ Associate Professor, Civil Engineering, Maulana Azad National Institute of Technology, Bhopal, India
}

\begin{abstract}
Engineers often face the problem of constructing facilities on or with soils, which do not posses sufficient strength to support the loads imposed upon them either during construction or during the service life of the structure. Vast areas of India consist of Black Cotton Soil which has high clay content, low strength and minimal bearing capacity. The poor engineering performance of such soils has forced Engineers device cost effective and ecofriendly methods for improving the engineering properties of poor soils. As the conventional soil stabilizers like gravel, sand, etc. are depleting and becoming expensive day by day at a very rapid pace, it becomes necessary to look towards for alternative ecofriendly stabilizers as their substitute. Recently many Bio-enzymes have emerged as cost effective stabilizers for soil stabilization. One such bio-enzyme, Terrazyme, has been used in the present work to study its effect on the Unconfined Compressive strength of the Black Cotton soil. It has been found that Terrazyme treated Black Cotton soil shows significant increase in Unconfined Compressive strength with longer curing period.
\end{abstract}

Keywords: Bio-enzyme, Terrazyme, Soil Stabilization and Black Cotton Soil.

\section{INTRODUCTION}

A large part of central India and a portion of South India are covered with Black Cotton soils. These soils are residual deposits formed from basalt or trap rocks. Black cotton soils are clays of high plasticity. They contain essentially the clay mineral montmorillonite, which is the most unstable clay mineral, thus the soils have high shrinkage and swelling characteristics. The sharing strength of the soil is extremely low, is highly compressible and has very low bearing capacity. It is very difficult to work with this soil, as do not posses sufficient strength to support the loads imposed upon them either during construction or during the service life of the structure. For better performance of structures built on such soils, the performance characteristics of such soils need to be improved. The poor engineering performance of such soils has forced Engineers to attempt to improve the engineering properties of poor quality soils. There are various methods that could be used to improve the performance of poor quality soils. These methods range from replacing it with a good quality soil to methods that involve complex chemical process. The choice of a particular method depends mainly on the type of soil to be improved, its characteristics and the type and degree of improvement desired in a particular application. Recently bio-enzymes have emerged as a new chemical for soil stabilization. Bio-enzymes are chemical, organic, and liquid concentrated substances which are used to improve the stability of soil sub-grade for pavement structures. BioEnzyme is convenient to use, safe, effective and dramatically improves road quality.

\subsection{Terrazyme, a Bio-Enzymatic Soil Stabilizer}

TerraZyme is a natural, non-toxic, non-corrosive and noninflammable liquid, produced by formulating vegetable extracts. Organic enzymes come in liquid form. They are perfectly soluble in water, brown in color with smell of molasses. Their aroma has no effect. Neither gloves nor masks are required during handling. TerraZyme is specially formulated to modify the engineering properties of soil. They require dilution in water before application. TerraZyme when added to water and mixed with soil alters the engineering properties depending upon the type of the soil and dosage of enzyme. These enzymes are liquid additives, which act on the soil to reduce the voids between soil particles and minimize absorbed water in the soil for maximum compaction. The enzymes react with the organic matter (humid matter) in the soil to form cementatious material. This decreases the swelling capacity of the soil particles and reduces permeability. The application of TerraZyme enhances weather resistance and increases load bearing capacity of soils. These features are particularly evident in fine-grained soils such as clay in which the formulation affects the swelling and shrinking behavior. The reaction is at micron level and the presence of finely divided humid matter and clay-sized particles is essential. Presence of clay is essential as the bonds formed bind this size of particles. The formulation has the ability to change the matrix of the soil so that after compaction the soil loses its ability to reabsorb water and the mechanical benefits of compaction are not lost even after water is reapplied to the compacted soil. Once the enzyme reacts with the soil, the change is permanent and the product is bio-degradable. 


\subsection{Mechanism of Soil Stabilization by Bio-Enzyme}

In clay water mixture positively charged ions (cat-ions) are present around the clay particles, creating a film of water around the clay particle that remains attached or adsorbed on the clay surface. The adsorbed water or double layer gives clay particles their plasticity. In some cases the clay can swell and the size of double layer increases, but it can be reduced by drying. Therefore, to truly improve the soil properties, it is necessary to permanently reduce the thickness of double layer. Cat-ion exchange processes can accomplish this. By utilizing fermentation processes specific micro-organisms can produce stabilizing enzyme in large quantity. These soil-stabilizing enzymes catalyze the reactions between the clay and the organic cat-ions and accelerate the cat-ionic exchange without becoming part of the end product.

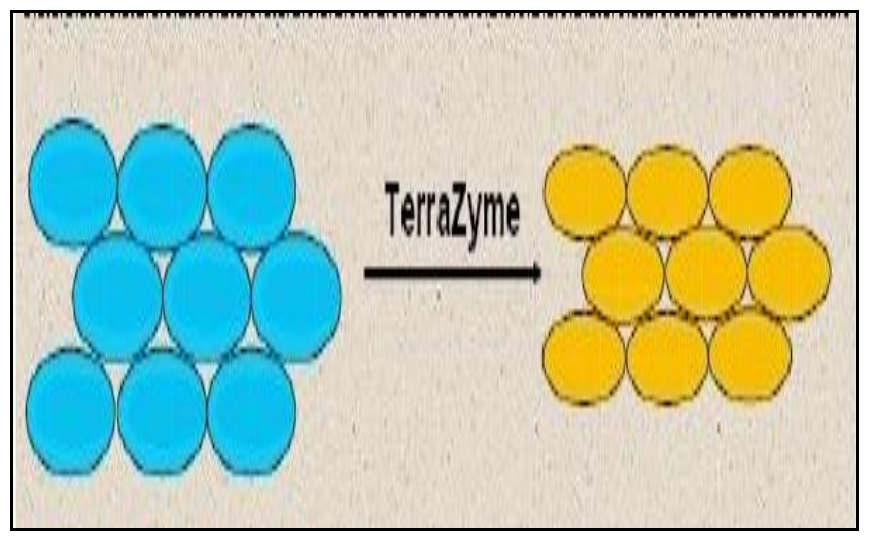

TerraZyme replaces adsorbed water with organic cations, thus neutralizing the negative charge on a clay particle. The organic cations also reduce the thickness of the electrical double layer. This allows TerraZyme treated soils to be compacted more tightly together.

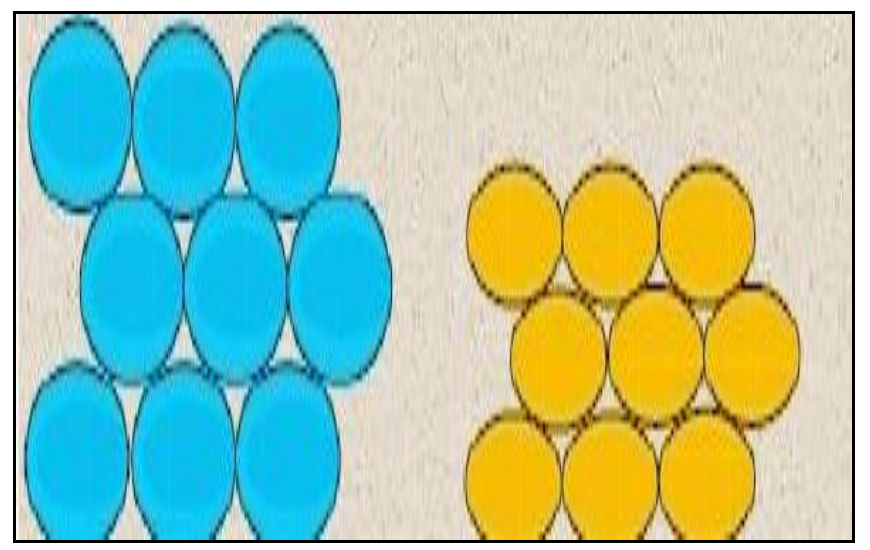

TerraZyme resists being replaced by water, thus reducing the tendency of some clay to swell.

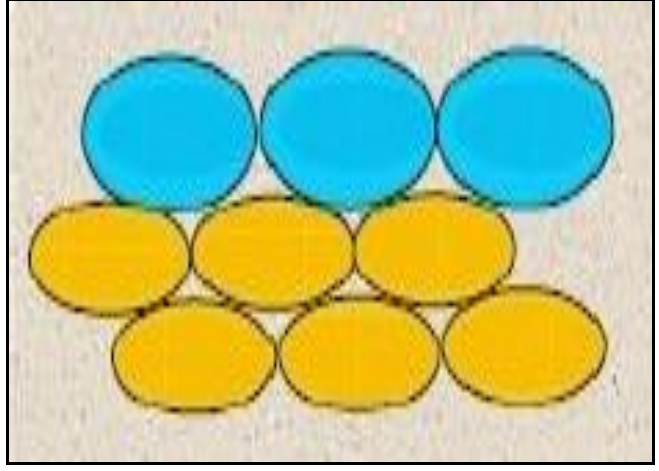

TerraZyme promotes the development of cementatious compounds using the following, general reaction:

\section{Terrazyme \\ $\mathrm{H}_{2} \mathrm{O}+$ Clay $\longrightarrow$ Calcium Silicate Hydrates}

\section{LITERATURE REVIEW}

Lacuoture and Gonzalez (1995) conducted a comprehensive study of the TerraZyme soil stabilizer product and its effectiveness on sub-base and sub-grade soils. The reactions of the soils treated with the enzyme was observed and recorded and compared to the untreated control samples. The variation in properties was observed over a short period only and it was found that in cohesive soils there was no major variation in properties during the early days but the soil showed improved performance progressively. Bergmann (2000) concluded through studies that Bio-Enzymes need some clay content to strengthen the soils. It was observed that at least $2 \%$ clay is needed for successful stabilization whereas 10 to $15 \%$ clay gave very good results. Shukla et al. (2003) used Bio-Enzymes to stabilize five different types of soil ranging from low clay content to very high clay content, engineering properties and strength characteristics were determined and it was found that there is little to high improvement in physical properties. Little improvement could be due to soil constituent, which has low reactivity with Bio-Enzymes. There was improvement in CBR and unconfined compression strength of soils like silty soil to sandy soil. An increase of 65 to $252 \%$ in UCS value was observed after 4 weeks of curing. Pavement design thickness also reduces to 25 to 40 percent. Moreover, in case of scarcity of granular material, only stabilized surface with thin bituminous surfacing can fulfill the pavement design requirement. Sharma (2006) has conducted laboratory studies on use of bio-enzyme stabilization of three types of soils namely clay of high plasticity $(\mathrm{CH})$, clay of low plasticity (CL) and silt of low plasticity (ML). It was found that the $\mathrm{CH}$ soil had an increase in CBR value with reduction in saturation moisture from 40 to $21 \%$ after 4 weeks of stabilization. Also it was found that there was $100 \%$ increase in unconfined compression strength. Shankar et al. (2009) studied the effect of different dosages of Bio-Enzymes on Lateritic soil of Dakshina Kannada (district of India), having liquid limit and 
Plasticity Index more than $25 \%$ and $6 \%$ respectively. Tests were conducted on lateritic soil by adding different percentages of sand as well. They concluded that there is medium improvement in physical properties of lateritic soil. Therefore it was suggested that effect of Bio-Enzyme on soil should be examined in laboratory before actual field application. Higher dosage $(200 \mathrm{ml} / 2 \mathrm{~m} 3$ of soil $)$ produced $300 \%$ increase in CBR, $450 \%$ in unconfined compressive strength and permeability was reduced by $42 \%$ after four weeks of curing. It was also observed that enzyme is not effective for cohesion less soil. Venkatasubramanian \& Dhinakaran (2011) conducted tests on three soils with varied properties and different dosages of Bio-Enzyme. Three soils had liquid limits of 28,30 and $46 \%$ and plasticity index of 6,5 and $6 \%$. Increase in unconfined compressive strength after 4 weeks of curing was reported as 246 to $404 \%$.

\section{EXPERIMENTAL INVESTIGATION}

The materials used for the tests include the Black cotton soil and TerraZyme (Bio-Enzyme). The Black cotton soil obtained from the field was tested in the laboratory for Unconfined Compressive Strength. The Unconfined Compressive Strength was evaluated by stabilization with variable dosages of enzyme $(0.0,0.25 \mathrm{ml}, 0.5 \mathrm{ml}, 0.75 \mathrm{ml}, 1.0 \mathrm{ml}, 2.0 \mathrm{ml}, 3.0 \mathrm{ml}$, and $4.0 \mathrm{ml} / \mathrm{per} 5 \mathrm{~kg}$ of soil) for one and seven days of curing. The specimen was prepared and kept in desecrator to retain moisture of the sample so that reaction between soil particle and TerraZyme may be continued. The test results have been given in table 1.

Table -1: UCS values $\left(\mathrm{kN} / \mathrm{m}^{2}\right)$ of soil treated with enzyme.

\begin{tabular}{|c|c|c|}
\hline \multirow{2}{*}{$\begin{array}{c}\text { DOSAGE } \\
\begin{array}{c}\text { (ml of Enzyme } \\
\text { /5kg of soil })\end{array}\end{array}$} & $\begin{array}{c}|c| \\
\text { Curing } \\
\text { Period } \\
\text { 1 Day }\end{array}$ & $\begin{array}{c}\text { Curing Period } \\
\text { 7 Day }\end{array}$ \\
\cline { 2 - 3 } & \multicolumn{2}{|c|}{690} \\
\hline Untreated & 1223 & 1471 \\
\hline $\mathbf{0 . 2 5}$ & 1487 & 1588 \\
\hline $\mathbf{0 . 5 0}$ & 1567 & 1718 \\
\hline $\mathbf{0 . 7 5}$ & 1659 & 1853 \\
\hline $\mathbf{1 . 0 0}$ & 1789 & 1937 \\
\hline $\mathbf{2 . 0 0}$ & 1874 & 2011 \\
\hline $\mathbf{3 . 0 0}$ & 1948 & 2075 \\
\hline $\mathbf{4 . 0 0}$ & & \\
\hline
\end{tabular}

The percentage increase in UCS with the increase in dosage of Terrazyme (from $0.25 \mathrm{ml}$ upto $4 \mathrm{ml} / 5 \mathrm{~kg}$ of soil) for curing periods of one and seven days are shown in Figure 1 \& Figure 2 respectively. The relative increase in UCS value from one to seven day of curing is shown in figure 3 .

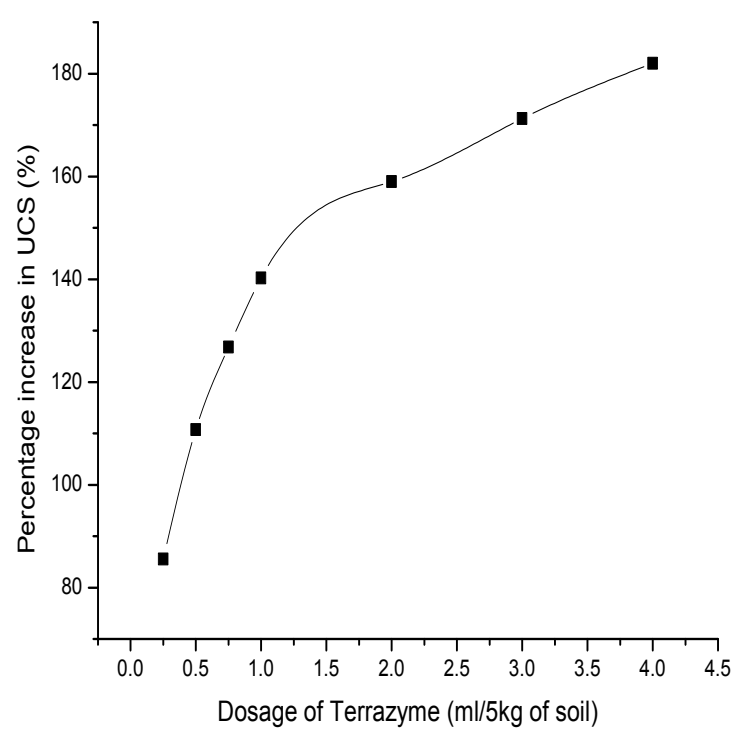

Fig 1: Percentage increase in U.C.S. after 1 day of curing.

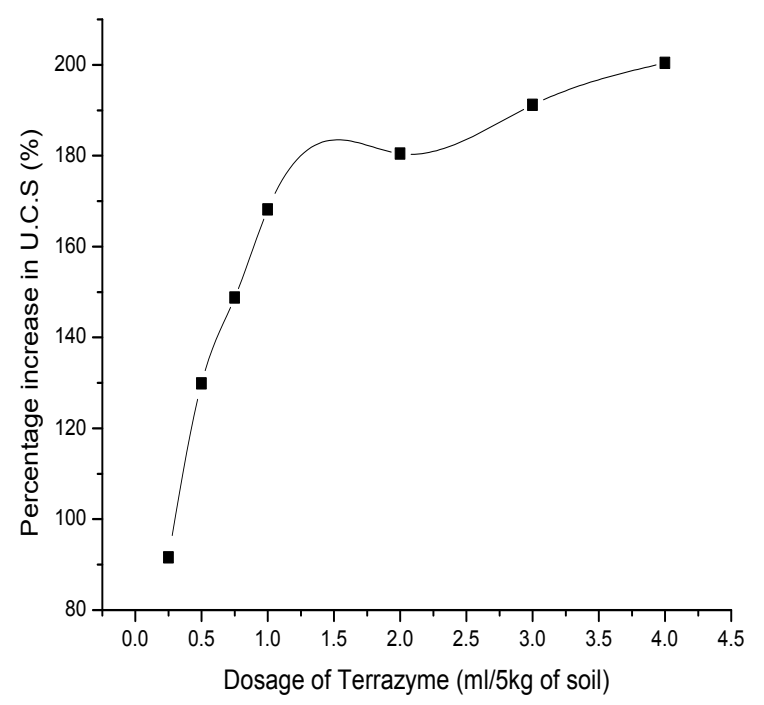

Fig 2: Percentage increase in U.C.S. after 7 day of curing. 


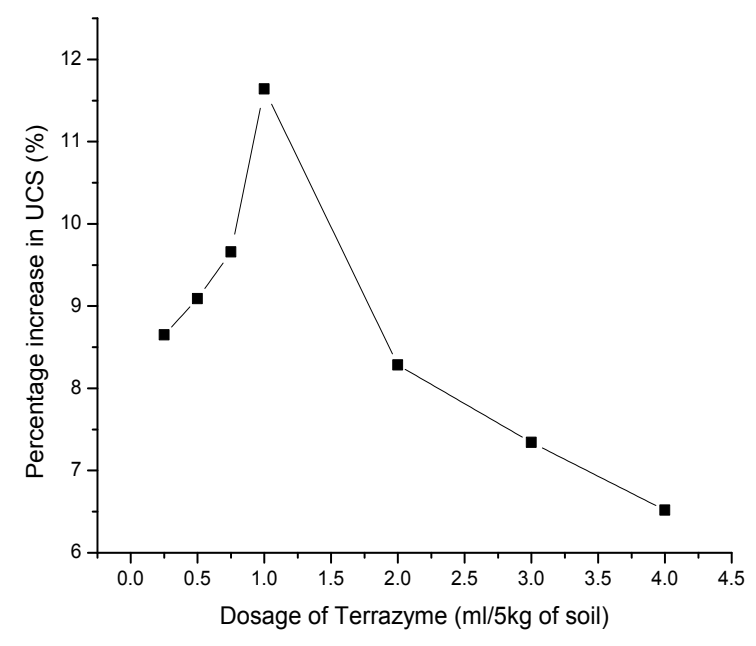

Fig 3: Relative increase in U.C.S. from 1 to 7 days of curing.

Figure $1 \& 2$ clearly shows that the rate of increase of U.C.S. drops significantly after $1 \mathrm{ml}$, and from figure 3 it can be observed that the relative rate of increase in the UCS value from 1 to 7 days of curing is maximum at Terrazyme dosage of $1 \mathrm{ml}$. Thus keeping economic criteria (getting maximum strength at minimum cost) in mind the optimum dosage of Terrazyme for improving the UCS of Black Cotton soil is about $1 \mathrm{ml} / 5 \mathrm{~kg}$ of soil.

\section{CONCLUSIONS}

Based on the tests conducted the following conclusions have been drawn:-

- $\quad$ Stabilization of the soil using Terrazyme resulted in significant increase in the Unconfined Compressive Strength of the Black Cotton Soil upto 200\%.

- Duration of treatment of soil with Terrazyme played a vital role in improvement of strength and soil treated with Terrazyme for 7 days gives higher strength.

- The optimum dosage of Terrazyme for improvement of UCS of Black Cotton soil is $1 \mathrm{ml} / \mathrm{per} 5 \mathrm{~kg}$ of soil.

- This eco-friendly enzyme i.e. Terrazyme can be effectively used to increase the Unconfined Compressive Strength of the Black Cotton soil.

\section{REFERENCES}

[1] A.U. Ravi Shankar, Harsha Kumar Rai and Ramesha Mithanthaya I. (2009): "Bio-enzyme Stabilized Lateritic Soil as a Highway Material", Journal of Indian Road Congress, Paper No. 553.

[2] Bergmann, R (2000) "Soil stabilizers on universally accessible trails". USDA Forest Service, San Dimas Technology and Development Center.
[3] Brazetti, R., and Murphy, S.R. (2000): "General usage of Bio-Enzyme stabilizers in Road Construction in Brazil", 32nd annual meeting on paving, Brazil.

[4] C. Venkatasubramanian and G. Dhinakaran, (2011): "Effect of Bio-Enzymatic Soil stabilization on unconfined compressive strength and california bearing ratio", Jornal of Engineering and Applied Sciences 6(5): 295-298.

[5] Chandrasekhar, B.P (2006) "A Critical review of innovative rural road construction techniques and their impacts", NRRDA, New Delhi.

[6] Dhinakaran, C. and Prasanna K.R. (2007): "Bioenzyme soil stabilization in road construction", Everyman's Science, Vol.XLI No.6, pp.397-400.

[7] Dr. K.P. Isaac, P.B. Biju and Dr. A. Veeraragavan, (2003): "Soil Stabilisation using bio-enzyme for Rural Roads", (IRC Seminar: Integrated Development of Rural and Arterial Road Networks for Socio-Economic development), New Delhi.

[8] Hitam, A. and Yusof, A. (1998): "Soil stabilizers for plantation road", Proceedings, National seminar on Mechanization in Oil Palm Plantation, Selangor, Malaysia, pp.124-138.

[9] Lacuoture, A. \& Gonzalez, H. (1995). "Usage of organic enzymes for the stabilization of natural base soils and sub-bases in bagota". Pontificia Universidad Jevariana, Faculty of Engineering.

[10] Manoj Shukla, Dr. Sunil Bose and Dr. P.K. Sikdar, (2003): "Bio-Enzyme for Stabilization of Soil in Road Construction- A Cost Effective Approach", (IRC Seminar: Integrated Development of Rural and Arterial Road Networks for Socio-Economic development), New Delhi.

[11] Marasteanu, M. O., Hozalski, R., Clyne, T. R. \& Velasquez, R. (2005). "Preliminary laboratory investigation of enzyme solutions as a soil stabilizer". Minnesota Department of Transportation, Research Services.

[12] Sureka Naagesh and S. Gangadhara (2010), "Swelling Properties of Bio-enzyme Treated Expansive soil". International Journal of Engineering Studies, ISSN 0975- 6469 Volume 2, Number 2 (2010), pp. 155-159.

[13] The Carbon Group, LLC. "Perma-Zyme 11x soil stabilization for road construction and natural liners". 